\title{
correspondence
}

\section{Sunspots and flu: a correlation}

SiR,--Seasonality exerts a profound but ill-understood influence on epidemic influenza. North of the tropic of Cancer and south of Capricorn epidemics usually break out in winter when the relevant portion of the globe of the Earth is most distant from the Sun. The purpose of this note is to call attention to a longer-term association of type A influenza with solar activity that has become apparent since human influenza virus was discovered in the epidemic of 1932-33, namely that the periods of world-dominance of successive major subtypes of influenza $A$ virus have synchronised closely with the periodicity of sunspots (see Figure). The two sets of cycles are probably synchronised at least as far back as 1917.

Influenza pandemics have occurred in the twelve months after type A influenza virus has undergone an antigenic shift leading to a new major subtype. The new major variant with altered haemagglutinin (H) and neuraminidase (N) finds the population inadequately protected by influenza caused by its predecessor. The change has enabled it to bypass their immunity. The predecessor promptly disappears and the new major variant with its minor varieties dominates the world causing all the type $A$ influenza for the next decade or so until itself displaced by the next antigenic shift. The major subtypes since 1933 have been identified serially according to $\mathrm{H} \& \mathrm{~N}$ composition as $\mathrm{H}_{0} \mathrm{~N}_{1}$ viruses isolated before 1947, $\mathrm{H}_{1} \mathrm{~N}_{1}$ 1947-1957, $\mathrm{H}_{2} \mathrm{~N}_{2}$ 1957-1968, $\mathrm{H}_{3} \mathrm{~N}_{2}$ 1968-1978. Each major subtype completely disappeared at the next antigenic shift except that $\mathrm{H}_{1} \mathrm{~N}_{1}$ viruses reappeared in many parts of the world in 1977 and are still (28 July 1978) causing influenza concurrently with $\mathrm{H}_{3} \mathrm{~N}_{2}$ viruses. The pandemic of 1918 is usually attributed to antigenic shift producing the major subtype $\mathrm{HSW}_{1} \mathrm{~N}_{1}$. A small outbreak caused by virus of this major subtype recurred in 1976.

Sunspots undergo cycles of activity varying from seven to seventeen years, average eleven years. Activity increases to maximum more rapidly than it declines to minimum, and maxima sometimes stand upon a plateau of several years of approximately equal activity. The true solar sunspot cycle consists of two consecutive cycles of minimum to minimum activity (see Gibson, Edward G. Rev. Geophys. Space Phys. 10, 395-462; 1972). Antigenic shifts of influenza $A$ virus to $\mathrm{H}_{1} \mathrm{~N}_{1}, \mathrm{H}_{2} \mathrm{~N}_{2}$ and $\mathrm{H}_{3} \mathrm{~N}_{2}$ coincided with sunspot maxima of 1947, 1957 and 1968 respectively. The sunspot maximum of 1937 coincided with severe and widespread influenza, but no antigenic shift was recorded. The sunspot maximum of 1928 coincided with a pandemic which may have signalised the antigenic shift from $\mathrm{HSw}_{1} \mathrm{~N}_{1}$ to $\mathrm{H}_{0} \mathrm{~N}_{1}$ virus. The previous sunspot maximum of 1917 anticipated the pandemic of $1918-19$. Fascinating as it is to attempt to investigate the association throughout the centuries of sunspot records, influenza records are probably too dubious to make the attempt worthwhile. The next sunspot maximum is however to be expected shortly, perhaps in 1979. The behaviour of type A influenza virus during the next few seasons will be watched with keen interest tinged with apprehension.

Yours faithfully, R. E. HOPE-SIMPSON

Epidemiological Research Unit, Cirencester, $U K$

\section{Racism}

SIR,-Professor Eysenck's clear dissociation from the National Front and other 'explicitly' racist organisations is to be welcomed, and I assume that he will be taking steps to ensure that the organisation and its associated journals cease using his name. In the meantime, although I am sure that when he denies that he has given an interview to The Beacon he does so in good faith, a further clarification seems required, as 1 have in my possesion a xerox copy of an issue of
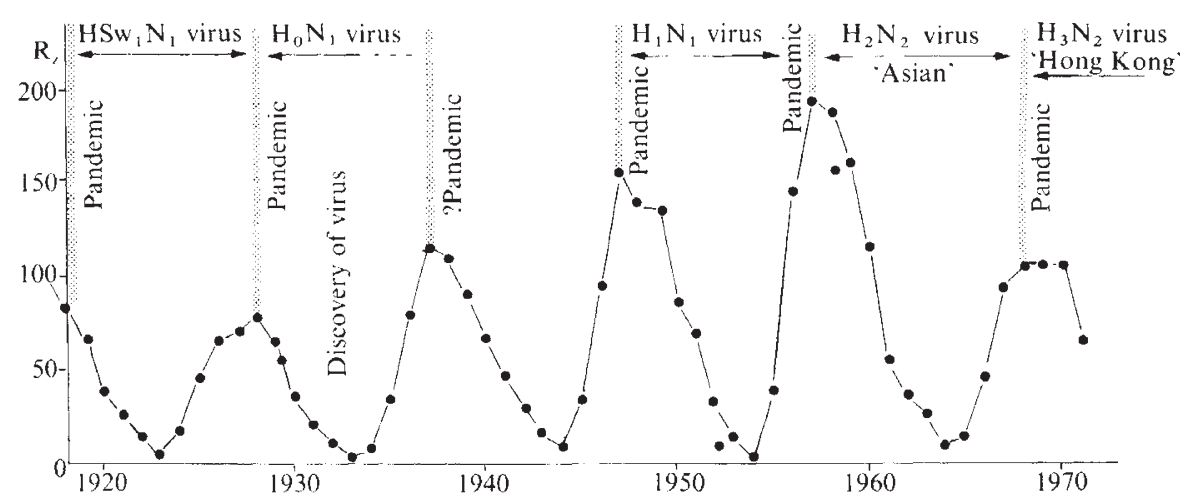

Sunspot cycles and major variants of influenza $A$ virus. Changes of major variant occurred abruptly with disappearance of predecessor variant. $R_{z}:$ Zurich yearly means of daily Relative Sunspot Numbers
The Beacon containing an interview in the form of questions and answers between someone described as a Beacon reporter and someone The Beacon describes as Professor Eysenck. Could the granting of this interview, by one who gives so many, have slipped his mind?

However, the most serious problem with the answers to my letter (Nature 274, $738 ; 1978$ ) is that both Professors Eysenck and Jensen fall yet again into the typological trap of the confusion of social and biological categories. To speak of "racial mean differences" to is do the reverse of to "treat each person

individually", which Professor Eysenck claims he wants; it is to categorise them as belonging to a group, which although socially defined (eg, Black, Jewish) Professors Eysenck and Jensen regard as having biological meaning. The resulting scientific errors which flow from their attempts to biometrise group characteristics are apparent to most biologists. As the National Front propaganda has shown, racist ideology feeds on this biologising thinking, and it needs firm public rebuttal. Yours faithfully,

Open University, Steven Rose Milton Keynes, UK

\section{Origins of "ecology"}

SIR,-In reviewing the book by $D$. Worster, Nature's Economy, Kenneth Mellanby (Nature, 6 April 1978) states that Haeckel "is believed to have coined the word [ecology] in 1873". I do not know if the word was used earlier, but it is certainly true that Ernst Haeckel in his volume, Generelle Morphologie der Organismen, Berlin, 1866, Vol. 2 ("Allgemeine Entwicklungsgeschichte der

Organismen"), p 286, states: "Unter Oecologie verstehen wir die gesammte Wissenschaft von den Beziehungen des Organismus zur umgebenden Aussenwelt", $\mathrm{He}$ therefore gives the correct definition of ecology, as we understand it today. Haeckel goes on (p 287): "Dagegen hat sie die Beziehungen desselben zur Aussenwelt, die Stellung, welche jeder Organismus im Naturhaushalt, in der Oeconomie des Natur-Ganzen einnimmt, in hohem Grade vernachlässigt".

Haeckel's definition of ecology, integrated with the concept of ecology as the study of the "economy of nature", is repeated in Haeckel's popular collections of lectures, Natürliche Schöpfungsgeschichte (1868), and Anthropogenie (1874). Both books were translated into many languages, and had dozens of editions, containing increasing numbers of 'lectures'. Readers may like to refer to a short history of the concepts of 'ecology' and of the 'economy of nature' in my paper: "Ecologia e economia", Giornale degli

Economisti, 32, 435-455 (1973). Yours faithfully,
Giorgio NeBria

Università di Bari, Italy 